\title{
Synthesis and Antispasmodic Activity Evaluation of Bis-(Papaverine) Analogues
}

\author{
Jaskiran KAUR, ${ }^{a}$ Narendra Nath GHOSH, ${ }^{b}$ and Ramesh CHANDRA $*, b$ \\ ${ }^{a}$ Department of Chemistry, University of Pennsylvania; Philadelphia, Pennsylvania, 19104, U.S.A.: and ${ }^{b}$ Dr. B. R. \\ Ambedkar Centre for Biomedical Research, University of Delhi; 110007, Delhi, India. \\ Received October 10, 2003; accepted December 22, 2003
}

\begin{abstract}
A new series of $N$-substituted bis-(tetrahydropapaverine) ring systems have been synthesised in expectation of better antispasmodic activity in comparison with papaverine. The synthesis of the targeted heterocycles is described along with a discussion of their structure activity relationship. The general synthetic methods of bis(tetrahydropapaverine) analogues involve tetrahydropapaverine, various piperazines, diisocyanates and diisothiocyanates as starting materials. Pharmacological evaluation involves the in vitro antispasmodic activity on a freshly removed guinea pig ileum using a force displacement transducer amplifier connected to a physiograph. Among the analogues synthesized in the present study, $N, N^{\prime}$-bis-[2-carbamoyl-1-(3,4-dimethoxybenzyl)-6,7dimethoxy-1,2,3,4-tetrahydroisoquinolinyl]piperazine (22), was found to be the most potent muscle relaxant $\left(\mathrm{IC}_{50}: 0.31 \mu \mathrm{M}\right)$.
\end{abstract}

Key words papaverine; tetrahydropapaverine; dimer; antispasmodic activity; piperazine; urea

Compounds containing symmetrical dimers of a number of natural molecules are of increasing importance in biochemical as well as in medicinal chemistry research. ${ }^{1)}$ The bis(naphthalimide) DMP-840 (Fig. 1) shows antineoplastic activity against a variety of human solid tumor cell lines in culture ${ }^{2,3)}$ and as xenografts in nude mice, ${ }^{4,5)}$ and is in clinical trial. ${ }^{6,7)}$ Other examples under study include bis-(benzonapthalimides) ${ }^{8)} \quad$ bis-(imidazoacridiones), ${ }^{9,10)}$ bis-(triazoloacridinones) ${ }^{11)}$ bis-(anthracyclines), ${ }^{12,13)}$ bis-(acridine-4carboxamides) ${ }^{14)}$ bis-(phenazine-1-carboxamides) ${ }^{15,16)}$ and bis-(indeno[1,2-b]quinoline-6-carboxamides). ${ }^{17)}$ A comparative study of a variety of bis analogues with their monomeric counterparts has revealed that there are variable but significant gains in potency for the dimeric species. ${ }^{18)}$ Due to interesting biological activities and unique chemical structures, bis analogues of various naturally occurring alkaloids serve as lead compounds for discovery of new drugs. ${ }^{19)}$

Dimeric analogues of a number of classes of chromophores joined by various cyclic and acyclic linkers are also of current interest as potential antispasmodic agents. ${ }^{20)}$ Natural bis-(isoquinoline) alkaloids have emerged as an important structural class based upon their high degree of bio-
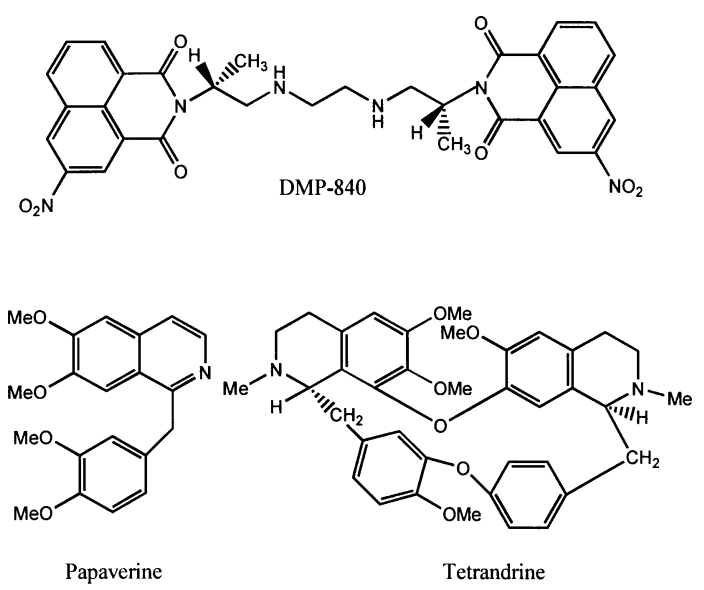

Fig. 1 logical activity. ${ }^{21)}$ A typical example is tetrandrine, ${ }^{22)}$ a potent antispasmodic agent. Papaverine, a benzylisoquinoline alkaloid, is a well known smooth muscle relaxant and a vasodilator. ${ }^{23,24)}$ Considering these factors and in continuation to our earlier efforts ${ }^{25,26)}$ of finding a potent antispasmodic agent, we envisaged that dimers of papaverine with suitable linkers at nitrogen can turn out to be more potent antispasmodic agents in comparison to papaverine.

Herein, we report the synthesis and antispasmodic activity of a series of bis-(tetrahydropapaverine) analogues with urea and acetyl linkers.

\section{Results and Discussion}

For the purpose of this study, numerous bis-(tetrahydropapverine) analogues $\mathbf{6}-\mathbf{1 3}$ were readily prepared by direct reaction of tetrahydropapaverine (5) (2 molar equivalent) with the corresponding (i) substituted bis-(isocyanates) and (ii) substituted bis-(isothiocyanates) in acetonitrile (Chart 1). In a typical reaction amide 3 required for the synthesis of tetrahydropapaverine (5) was prepared by the condensation of homoveratryl amine (1) and homoveratric acid (2) in xylene with azeotropic removal of water. Cyclization of amide 3 to 3,4-dihydroisoquinoline (4) was achieved in Bischler-Napierlaski fashion, in refluxing toluene with phosphorous oxychloride. Reduction of 3,4-dihydroisoquinoline with sodium borohydride in methanol resulted in the formation of tetrahydropapaverine 5 (Chart 1). ${ }^{26)}$ Products $\mathbf{6}-\mathbf{- 1 3}$ were obtained in $80-85 \%$ yield and were purified by column chromatography.

Reaction of tetrahydropapaverine (5) with chloroacetylchloride and triethylamine in dichloromethane lead to the formation of $N$-(chloroacetyl)tetrahydropapaverine (14). The reaction of tetrahydropapaverine (5) and $N$-(chloroacetyl)tetrahydropapaverine (14) in acetone in the presence of potassium carbonate and tetrabutylammonium iodide at room temperature yielded 15 (Chart 2). The direct reaction of $N$ (chloroacetyl)tetrahydropapaverine (14) (2 molar equivalent) with piperazine or cis-2,6-dimethylpiperazine or homopiperazine (1 molar equivalent) in acetone in the presence of 


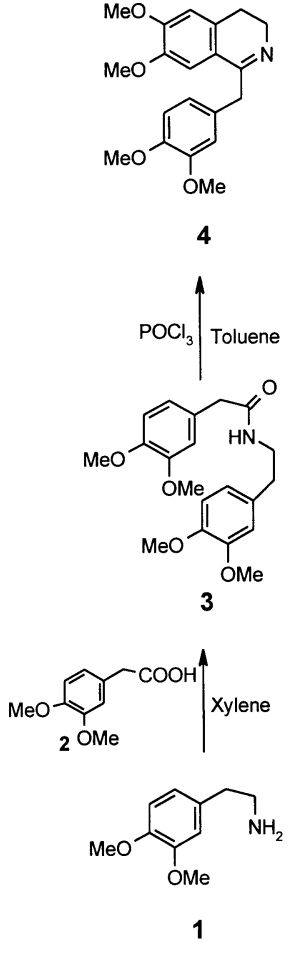

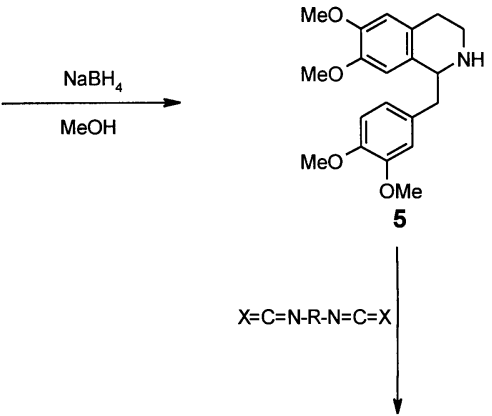
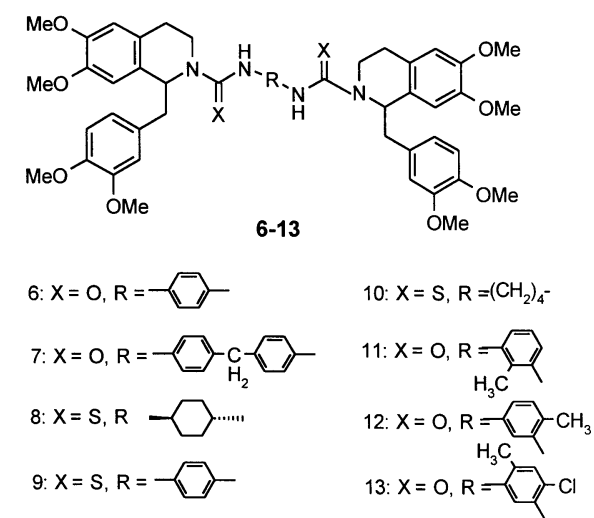

Chart 1<smiles>COc1ccc(CC2NCCc3cc(OC)c(OC)cc32)cc1OC</smiles>

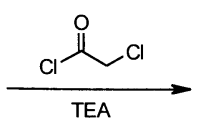<smiles>COc1ccc(CC2c3cc(OC)c(OC)cc3CCN2C(=O)CCl)cc1OC</smiles><smiles>COc1ccc(CC2c3cc(OC)c(OC)cc3CCN2C(=O)CN2CCc3cc(OC)c(OC)cc3C2Cc2ccc(OC)c(OC)c2)cc1</smiles>

Chart 2

potassium carbonate and tetrabutylammonium iodide yielded 16-18 respectively (Chart 3). Products 16-18 were purified by column chromatography eluting with ethylacetate and hexane and obtained in $73-76 \%$ yields.

Tetrahydropapaverine efficiently displaced one of the imidazole rings of carbonyldiimidazole ${ }^{26)}$ to give tetrahydropapaverine carbamoyl imidazole 19 on refluxing it with carbonyldiimidazole (CDI) in tetrahyrofuran (THF) for $24 \mathrm{~h}$. The reaction of methyl iodide with carbamoyl imidazole 19 (4 molar equivalents) in acetonitrile for one day at room temperature produced the imidazolium salt quantitatively. This imidazolium salt required no additional purification for final conversion to ureas. Addition of tetrahydropapaverine to a solution of imidazolium salt in dichloromethane with triethylamine at room temperature afforded tetra substituted urea derivative 21 (Chart 4). It was purified by column chromatogra- phy and obtained in $79 \%$ yield. The activation of the leaving imidazole ring was found to be necessary for the formation of desired ureas since the carbamoyl imidazoles were unreactive towards tetrahydropapaverine even under refluxing conditions for prolonged periods. Addition of triethylamine (1 molar equivalent) resulted in improved yields of ureas.

The reaction of imidazolium salt $\mathbf{2 0}$ ( 2 molar equivalent) with piperazine or $c i s-2,6$-dimethylpiperazine or homopiperazine (1 molar equivalent) in dichloromethane and triethylamine (Chart 5) afforded compounds 22-24 respectively. These compounds were purified by column chromatography and obtained in $75-80 \%$ yield.

Antispasmodic activity studies of compounds $\mathbf{6}-\mathbf{1 3}, \mathbf{1 5}$ 18, and 21-24 were performed on guinea pig ileum. Acetylcholine $\left(10^{-3} \mathrm{M}\right)$ was used to induce sustained contraction in guinea pig ileum. When the contraction response to acetylcholine reached a steady level, papaverine was added cumulatively. Papaverine inhibited the acetylcholine induced contraction in a concentration dependent manner. Similarly, acetylcholine induced contraction inhibition by tetrahydropapaverine derivatives $\mathbf{6}-\mathbf{1 3}, \mathbf{1 5}-\mathbf{1 8}$, and $\mathbf{2 1}-\mathbf{2 4}$ were studied. Dose-response curves were obtained for papaverine and all these derivatives. The results revealed that most of the test compounds $\mathbf{6}-\mathbf{1 3}, \mathbf{1 5}-\mathbf{1 8}$, and $\mathbf{2 1}-\mathbf{2 4}$ more potently inhibited the acetylcholine induced contractions than papaverine. Table 1 summarizes the concentration of papaverine and test compounds producing $50 \%$ relaxation $\left(\mathrm{IC}_{50}\right)$ of acetylcholine induced contraction for compounds 6-13 and Table 2 summarizes the $\mathrm{IC}_{50}$ values of compounds 15-18, and $\mathbf{2 1 - 2 4}$. $\mathrm{IC}_{50}$ values were determined graphically from dose-response curves obtained by measuring antispasmodic activity at six concentrations $(0.1,0.5,1.0,5.0,10,20 \mu \mathrm{M})$ of the compounds in duplicate of triplicates.

The structure activity relationship of these compounds has 

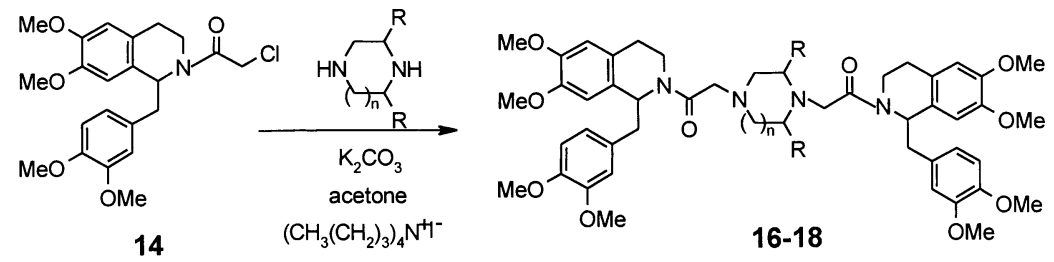

16: $R=H, n=1$

17: $\mathrm{R}=\mathrm{CH}_{3}, \mathrm{n}=1$

18: $R=H, n=2$

Chart 3<smiles>COc1ccc(CC2c3cc(OC)c(OC)cc3CCN2C(=O)n2ccnc2)cc1CC1CCCCC1Cn1ccnc1</smiles>

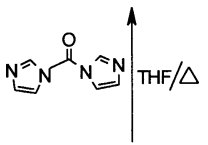

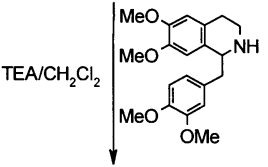<smiles>COc1ccc(Cc2cc3cc(OC)c(OC)cc3cc2OC)c(OC)c1</smiles><smiles>COc1ccc(CC2c3cc(OC)c(OC)cc3CCN2C(=O)N2CCc3cc(OC)c(OC)cc3C2)cc1OC</smiles>

Chart 4

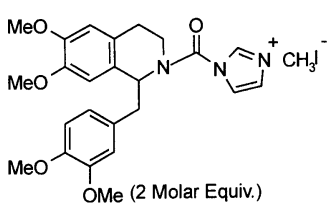

20

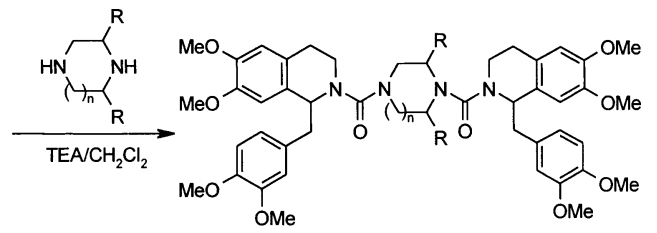

22- 24

$$
\begin{aligned}
& \text { 22: } R=H, n=1 \\
& \text { 23: } R=C_{3}, n=1 \\
& \text { 24: } R=H, n=2
\end{aligned}
$$

Chart 5

been focused on alterations in the linker chain. Three types of linkers have been introduced. First category of linkers consists of two urea moieties linked by spacers like benzene, substituted benzene, cyclohexane and butyl chain (6-13). Second category has piperazinyl, substituted piperazinyl ring placed between two acetyl groups, as linkers (15-18). Third category consists of piperazinyl, substituted piperazinyl ring placed between two carbamoyl groups, as linkers (21-24).

Among the three types of linkers, the compounds with third category of linkers $(\mathbf{2 1}-\mathbf{2 4})$ were found to be most potent. The corresponding compounds with $\mathrm{CH}_{2}$ spacers (1518), exhibited a decrease in antispasmodic activity. The compounds with trisubstituted urea spacers (6-13) were found to be least active among the bis-(tetrahydropapaverine) derivatives reported.

The bis-(tetrahydropapaverine) derivatives with trisubsti- tuted urea spacers 6-13 exhibited antispasmodic activities not significantly different from papaverine. Compound $\mathbf{6}$, with a benzene ring as a spacer, introduced between the two amide groups, gave $\mathrm{IC}_{50}$ value of $6.17 \mu \mathrm{M}$. Its thio analogue 9 exhibited a small decrease in antispasmodic activity. Substitution of a cyclohexane ring $\mathbf{8}$ in place of benzene ring decreased the antispasmodic activity $\left(\mathrm{IC}_{50}: 9.31 \mu \mathrm{M}\right)$. Compound $\mathbf{1 0}$ with an aliphatic chain as the spacer between the two thiomide groups exhibited $\mathrm{IC}_{50}$ value further lower as compared to compound 8. Compounds 11 and 12 having methyl group substituted in benzene ring were not as good antispasmodic agents as papaverine. They exhibited $\mathrm{IC}_{50}$ values similar to that exhibited by compounds 8 and 10. Substitution of a chloro group in addition to a methyl group in the benzene ring (13) enhanced the antispasmodic activity.

The bis-(tetrahydropapaverine) derivatives with acetyl 
Table 1. Concentration of Bis-(tetrahydropapaverine) Derivatives 6-13 Producing 50\% Relaxation $\left(\mathrm{IC}_{50}\right.$ ) of Acetylcholine Induced Contractions<smiles>COc1ccc(CC2c3cc(OC)c(OC)cc3CCN2C(=O)N2CCc3cc(OC)c(OC)cc3C2Cc2ccc(OC)c(OC)c2)cc1OC</smiles>

Compound

a) $\mathrm{IC}_{50}$ of papaverine $=7.31 \mu \mathrm{M} . \mathrm{IC}_{50 \mathrm{~s}}$ were calculated using a mean of at least 3 measurements (all duplicates) for 6 concentrations in the range $0.1-20 \mu \mathrm{M}$.

linkers 15-18 exhibited significantly higher antispasmodic activities in comparison to papaverine. Compound 15 exhibited an $\mathrm{IC}_{50}$ value of $0.61 \mu \mathrm{M}$. Introduction of a piperazine ring 16 between the two acetyl groups increased the antispasmodic activity $\left(\mathrm{IC}_{50}: 0.43 \mu \mathrm{M}\right)$. Methyl substitution (17) in the piperazine ring at positions 2 and 6 , lead to a fall in the activity $\left(\mathrm{IC}_{50}: 1.07 \mu \mathrm{M}\right)$. Substitution of homopiperazine ring (18) in place of piperazine ring slightly increased the activity $\left(\mathrm{IC}_{50}: 0.95 \mu \mathrm{M}\right)$.

Among the tetra substituted urea derivatives 21-24, the $\mathrm{IC}_{50}$ value of 21 was found to be $0.42 \mu \mathrm{M}$. Addition of a piperazine spacer between the two carbamoyl groups further increased the antispasmodic activity $\left(\mathrm{IC}_{50}: 0.31 \mu \mathrm{M}\right)$. Methyl substitution (23) on the piperazine ring at positions 2 and 6 , lead to a fall in the activity $\left(\mathrm{IC}_{50}: 0.75 \mu \mathrm{M}\right)$. Substitution of homopiperazine ring (24) in place of piperazine ring slightly increased the activity $\left(\mathrm{IC}_{50}: 70 \mu \mathrm{M}\right)$.

Compound $\mathbf{1 0}$ is the least potent and compound $\mathbf{2 2}$ is the most active bis-(tetrahydropapaverine) analogue of the series.

\section{Conclusion}

$N$-Substituted bis-(tetrahydropapaverine) derivatives showed better antispasmodic activity in comparison with papaverine in guinea pigs in preliminary screenings. Compounds with tetra substituted urea linkers were found to be more active than compounds with trisubstituted urea linkers and compounds with acetyl linkers. Compound 22 was found
Table 2. Concentration of Bis-(tetrahydropapaverine) Derivatives 15-18 and 21-24 Producing 50\% Relaxation $\left(\mathrm{IC}_{50}\right)$ of Acetylcholine Induced Contractions<smiles>COc1ccc(CC2c3cc(OC)c(OC)cc3CCN2CN2CCc3cc(OC)c(OC)cc3C2Cc2ccc(OC)c(OC)c2)cc1OC</smiles>

Compound

a) $\mathrm{IC}_{50}$ of papaverine $=7.31 \mu \mathrm{M} . \mathrm{IC}_{50 \mathrm{~s}}$ were calculated using a mean of at least 3 measurements (all duplicates) for 6 concentrations in the range $0.1-20 \mu \mathrm{m}$.

to be the most potent compound among the series. However, contrary to our predictions, none of the bis analogues were able to beat the best compound of our previously reported ${ }^{26}$ ) piperazinyl based tetra substituted urea derivative of papaverine.

\section{Experimental}

Melting points are recorded in open capillary tubes on Buchi melting point B-540 instrument and are uncorrected. Solvent system used throughout the experimental work for running TLC plates was ethylacetate-hexane. The ${ }^{1} \mathrm{H}-\mathrm{NMR}$ spectra were recorded in $\mathrm{CDCl}_{3}$ as solvent (using TMS as internal standard) on a Bruker Avance Spectrospin 300 instrument at $300 \mathrm{MHz}$. Mass spectra were run on a Perkin Elmer LCMS API-2000 mass spectrometer. IR spectra were recorded using $\mathrm{KBr}$ discs on a Shimadzu FTIR-8300 spectrophotometer. Elemental analysis was carried out on Heraeus Rapid $\mathrm{CHN}$ analyser.

$N, N^{\prime}$-[1,4-Benzene-\{diyl-bis-(iminocarbonyl)\}-bis-\{1-(3,4-dimethoxybenzyl)-6,7-dimethoxy-1,2,3,4-tetrahydroisoquinoline\}] (6) A solution of 1,4-phenylenediisocyanate $(0.192 \mathrm{~g}, 1.2 \mathrm{mmol})$ in dry acetonitrile $(5 \mathrm{ml})$ was added slowly to a solution of tetrahydropapaverine $5(0.686 \mathrm{~g}, 2 \mathrm{mmol})$ in dry acetonitrile $(5 \mathrm{ml})$. The mixture was stirred at room temperature for $2 \mathrm{~h}$. After the completion (TLC) of the reaction, evaporated off the solvent, diluted the residue with water $(25 \mathrm{ml})$ and extracted with ethylacetate $(3 \times 25 \mathrm{ml})$. The collective organic portion was washed with brine and dried $\left(\mathrm{Na}_{2} \mathrm{SO}_{4}\right)$. It was concentrated under reduced pressure and the residue was chromatographed on silica gel using ethylacetate-hexane as eluent. A final recrystallization from ethylacetate-hexane $(15: 85)$ afforded pure $\mathbf{6}$ as a viscous solid $(0.685 \mathrm{~g}, 81 \%)$. ${ }^{1} \mathrm{H}-\mathrm{NMR}\left(\mathrm{CDCl}_{3}, 300 \mathrm{MHz}\right) \delta: 2.60(4 \mathrm{H}, \mathrm{m})$, $3.10(4 \mathrm{H}, \mathrm{m}), 2.97(4 \mathrm{H}, \mathrm{m}), 3.29(4 \mathrm{H}, \mathrm{m}), 3.73(2 \times 3 \mathrm{H}, \mathrm{s}), 3.78(2 \times 3 \mathrm{H}, \mathrm{s})$, $3.81(2 \times 3 \mathrm{H}, \mathrm{s}), 3.85(2 \times 3 \mathrm{H}, \mathrm{s}), 5.01(2 \mathrm{H}, \mathrm{m}), 5.56(2 \mathrm{H}, \mathrm{s}), 6.41(2 \mathrm{H}, \mathrm{s})$, 
$6.56(2 \mathrm{H}, \mathrm{s}), 6.79(4 \mathrm{H}, \mathrm{m}), 6.97(6 \mathrm{H}, \mathrm{m}) . \mathrm{IR}(\mathrm{KBr}) v \mathrm{~cm}^{-1}: 1639$. MS $(\mathrm{m} / \mathrm{z})$ : $847(\mathrm{M}+\mathrm{H})^{+}$. Anal. Calcd for $\mathrm{C}_{48} \mathrm{H}_{54} \mathrm{~N}_{4} \mathrm{O}_{10}: \mathrm{C}, 68.06 ; \mathrm{H}, 6.42 ; \mathrm{N}, 6.61$. Found: C, 68.15; H, 6.31; N, 6.52 .

$N, N^{\prime}-\left[4,4^{\prime}-M e t h y l e n e-\{\right.$ diyl-bis-(phenyliminocarbonyl)\}-bis- $\{1-(3,4-$ dimethoxybenzyl)-6,7-dimethoxy-1,2,3,4-tetrahydroisoquinoline\}] (7) Synthesized, from tetrahydropapaverine (5) and 4,4'-methylene-bis(phenylisocyanate), in a manner similar to that described for $\mathbf{6}$. The product was obtained as a light yellow solid $(80 \%) \mathrm{mp} 122-123{ }^{\circ} \mathrm{C} .{ }^{1} \mathrm{H}-\mathrm{NMR}$ $\left(\mathrm{CDCl}_{3}, 300 \mathrm{MHz}\right) \delta: 2.67(4 \mathrm{H}, \mathrm{m}), 3.14(4 \mathrm{H}, \mathrm{m}), 3.43(4 \mathrm{H}, \mathrm{m}), 3.79$ $(2 \times 3 \mathrm{H}, \mathrm{s}), 3.82(2 \times 3 \mathrm{H}, \mathrm{s}), 3.83(2 \times 3 \mathrm{H}, \mathrm{s}), 3.87(2 \times 3 \mathrm{H}, \mathrm{s}), 4.11(2 \mathrm{H}, \mathrm{m})$, $5.02(2 \mathrm{H}, \mathrm{s}), 5.66(2 \mathrm{H}, \mathrm{s}), 6.48(2 \mathrm{H}, \mathrm{s}), 6.64(2 \mathrm{H}, \mathrm{s}), 6.74(4 \mathrm{H}, \mathrm{m}), 6.83(4 \mathrm{H}$ m), $6.99(6 \mathrm{H}, \mathrm{m})$. IR (KBr) $v \mathrm{~cm}^{-1}: 1640.5$. MS $(\mathrm{m} / \mathrm{z}): 937(\mathrm{M}+\mathrm{H})^{+}$. Anal. Calcd for $\mathrm{C}_{55} \mathrm{H}_{60} \mathrm{~N}_{4} \mathrm{O}_{10}$ : C, 70.49; H, 6.45; N, 5.97. Found: C, 70.35; H, $6.39 ; \mathrm{N}, 5.82$

$N, N^{\prime}$-[trans-Cyclohexane-\{diyl-bis-(iminothiocarbonyl)\}-bis- $\{1-(3,4-$ dimethoxybenzyl)-6,7-dimethoxy-1,2,3,4-tetrahydroisoquinoline\}] (8) Synthesized, from 5 and trans-1,4-cyclohexanediisothiocyanate, in a manner similar to that described for $\mathbf{6}$. The product was obtained as a light yellow solid $(85 \%) \mathrm{mp} 118-120^{\circ} \mathrm{C} .{ }^{1} \mathrm{H}-\mathrm{NMR}\left(\mathrm{CDCl}_{3}, 300 \mathrm{MHz}\right) \delta: 1.47(8 \mathrm{H}, \mathrm{m})$, $2.32(4 \mathrm{H}, \mathrm{m}), 2.78(4 \mathrm{H}, \mathrm{m}), 2.93(4 \mathrm{H}, \mathrm{s}), 3.23(2 \mathrm{H}, \mathrm{s}), 3.71(2 \times 3 \mathrm{H}, \mathrm{s}), 3.77$ $(2 \times 3 \mathrm{H}, \mathrm{s}), 3.83(4 \times 3 \mathrm{H}, \mathrm{s}), 4.88(2 \mathrm{H}, \mathrm{m}), 6.33(2 \mathrm{H}, \mathrm{m}), 6.58(6 \mathrm{H}, \mathrm{m}), 6.74$ $(2 \mathrm{H}, \mathrm{m})$. IR $(\mathrm{KBr}) v \mathrm{~cm}^{-1}: 1232$. MS $(\mathrm{m} / \mathrm{z}): 885(\mathrm{M}+\mathrm{H})^{+}$. Anal. Calcd for $\mathrm{C}_{48} \mathrm{H}_{60} \mathrm{~N}_{4} \mathrm{O}_{8} \mathrm{~S}_{2}: \mathrm{C}, 65.13 ; \mathrm{H}, 6.82 ; \mathrm{N}, 6.32$. Found: $\mathrm{C}, 65.51 ; \mathrm{H}, 6.65 ; \mathrm{N}$ 6.41 .

$N, N^{\prime}-[1,4-B e n z e n e-\{$ diyl-bis-(iminothiocarbonyl)\}-bis- $\{1-(3,4-$ dimethoxybenzyl)-6,7-dimethoxy-1,2,3,4-tetrahydroisoquinoline $\}]$

Synthesized, from 5 and 1,4-phenylenediisothiocyanate, in a manner similar to that described for $\mathbf{6}$. The product was obtained as a white solid $(85 \%) \mathrm{mp}$ $126-128^{\circ} \mathrm{C} .{ }^{1} \mathrm{H}-\mathrm{NMR}\left(\mathrm{CDCl}_{3}, 300 \mathrm{MHz}\right) \delta: 2.80(4 \mathrm{H}, \mathrm{m}), 3.24(8 \mathrm{H}, \mathrm{m})$, $3.75(2 \times 3 \mathrm{H}, \mathrm{s}), 3.83(2 \times 3 \mathrm{H}, \mathrm{s}), 3.87(4 \times 3 \mathrm{H}, \mathrm{s}), 5.29(2 \mathrm{H}, \mathrm{m}), 6.48(2 \mathrm{H}$, m), $6.60(6 \mathrm{H}, \mathrm{m}), 6.73(10 \mathrm{H}, \mathrm{m}) . \mathrm{IR}(\mathrm{KBr}) v \mathrm{~cm}^{-1}: 1260$. MS $(\mathrm{m} / \mathrm{z}): 879$ $(\mathrm{M}+\mathrm{H})^{+}$. Anal. Calcd for $\mathrm{C}_{48} \mathrm{H}_{54} \mathrm{~N}_{4} \mathrm{O}_{8} \mathrm{~S}_{2}: \mathrm{C}, 65.58 ; \mathrm{H}, 6.19 ; \mathrm{N}, 6.37$. Found: C, 65.51; H, 6.15; N, 6.42 .

$N, N^{\prime}-[1,4-B u t a n e-\{$ diyl-bis-(iminothiocarbonyl) $\}$-bis- $\{1-(3,4-$ dimethoxybenzyl)-6,7-dimethoxy-1,2,3,4-tetrahydroisoquinoline\}] (10) Synthesized, from 5 and 1,4-butanediisothiocyanate, in a manner similar to that described for $\mathbf{6}$. The product was obtained as a white solid $(83 \%) \mathrm{mp}$ $56-58^{\circ} \mathrm{C} .{ }^{1} \mathrm{H}-\mathrm{NMR}\left(\mathrm{CDCl}_{3}, 300 \mathrm{MHz}\right) \delta: 1.64(4 \mathrm{H}, \mathrm{m}), 2.90(4 \mathrm{H}, \mathrm{m}), 2.98$ $(4 \mathrm{H}, \mathrm{m}), 3.27(4 \mathrm{H}, \mathrm{m}), 3.58(4 \mathrm{H}, \mathrm{m}), 3.72(2 \times 3 \mathrm{H}, \mathrm{s}), 3.84(2 \times 3 \mathrm{H}, \mathrm{s}), 3.86$ $(4 \times 3 \mathrm{H}, \mathrm{s}), 5.12(2 \mathrm{H}, \mathrm{m}), 5.61(2 \mathrm{H}, \mathrm{m}), 6.30(2 \mathrm{H}, \mathrm{s}), 6.67(2 \mathrm{H}, \mathrm{m}), 6.79(6 \mathrm{H}$, m). IR $(\mathrm{KBr}) v \mathrm{~cm}^{-1}$ : 1254. MS $(\mathrm{m} / \mathrm{z}): 859(\mathrm{M}+\mathrm{H})^{+}$. Anal. Calcd for $\mathrm{C}_{46} \mathrm{H}_{58} \mathrm{~N}_{4} \mathrm{O}_{8} \mathrm{~S}_{2}: \mathrm{C}, 64.31 ; \mathrm{H}, 6.80 ; \mathrm{N}, 6.52$. Found: C, 64.49; H, 6.75; N, 6.42 .

$N, N^{\prime}$-[1,3-Benzene-\{diyl-bis-(iminocarbonyl)-2-methyl\}-bis- $\{1-(3,4-$ dimethoxybenzyl)-6,7-dimethoxy-1,2,3,4-tetrahydroisoquinoline\}] (11) Synthesized, from $\mathbf{5}$ and 2-methyl-m-phenylenediisocyanate, in a manner similar to that described for $\mathbf{6}$. The product was obtained as a white solid (81\%) mp 171-172 ${ }^{\circ} \mathrm{C} .{ }^{1} \mathrm{H}-\mathrm{NMR}\left(\mathrm{CDCl}_{3}, 300 \mathrm{MHz}\right) \delta: 2.70(4 \mathrm{H}, \mathrm{m}), 2.97$ $(4 \mathrm{H}, \mathrm{m}), 3.14(4 \mathrm{H}, \mathrm{m}), 3.44(3 \mathrm{H}, \mathrm{s}), 3.76(2 \times 3 \mathrm{H}, \mathrm{s}), 3.79(2 \times 3 \mathrm{H}, \mathrm{s}), 3.88$ $(4 \times 3 \mathrm{H}, \mathrm{s}), 5.12(2 \mathrm{H}, \mathrm{m}), 5.70(2 \mathrm{H}, \mathrm{m}), 6.30(2 \mathrm{H}, \mathrm{m}), 6.67(6 \mathrm{H}, \mathrm{m}), 6.79$ $(3 \mathrm{H}, \mathrm{m}), 6.91(2 \mathrm{H}, \mathrm{m})$. IR $(\mathrm{KBr}) v \mathrm{~cm}^{-1}: 1618$. MS $(\mathrm{m} / \mathrm{z}): 861(\mathrm{M}+\mathrm{H})^{+}$ Anal. Calcd for $\mathrm{C}_{49} \mathrm{H}_{56} \mathrm{~N}_{4} \mathrm{O}_{10}$ : C, 68.35; H, 6.55; N, 6.50. Found: C, 68.27; $\mathrm{H}, 6.65 ; \mathrm{N}, 6.41$.

$N, N^{\prime}$-[1,3-Benzene-\{diyl-bis-(iminocarbonyl)-4-methyl\}-bis-\{1-(3,4dimethoxybenzyl)-6,7-dimethoxy-1,2,3,4-tetrahydroisoquinoline\}] (12) Synthesized, from $\mathbf{5}$ and 4-methyl- $m$-phenylenediisocyanate, in a manner similar to that described for $\mathbf{6}$. The product was obtained as a viscous solid (82\%). ${ }^{1} \mathrm{H}-\mathrm{NMR}\left(\mathrm{CDCl}_{3}, 300 \mathrm{MHz}\right) \delta: 2.71(4 \mathrm{H}, \mathrm{m}), 2.95(4 \mathrm{H}, \mathrm{m}), 3.11$ $(4 \mathrm{H}, \mathrm{m}), 3.31(3 \mathrm{H}, \mathrm{s}), 3.73(2 \times 3 \mathrm{H}, \mathrm{s}), 3.79(2 \times 3 \mathrm{H}, \mathrm{s}), 3.86(4 \times 3 \mathrm{H}, \mathrm{s}), 5.10$ $(2 \mathrm{H}, \mathrm{m}), 5.70(2 \mathrm{H}, \mathrm{m}), 6.30(2 \mathrm{H}, \mathrm{m}), 6.71(6 \mathrm{H}, \mathrm{m}), 6.80(3 \mathrm{H}, \mathrm{m}), 7.01(2 \mathrm{H}$ m). IR $(\mathrm{KBr}) v \mathrm{~cm}^{-1}$ : 1620. MS $(\mathrm{m} / \mathrm{z}): 861(\mathrm{M}+\mathrm{H})^{+}$. Anal. Calcd for $\mathrm{C}_{49} \mathrm{H}_{56} \mathrm{~N}_{4} \mathrm{O}_{10}: \mathrm{C}, 68.35 ; \mathrm{H}, 6.55 ; \mathrm{N}, 6.50$. Found: $\mathrm{C}, 68.37 ; \mathrm{H}, 6.63 ; \mathrm{N}, 6.42$.

$\boldsymbol{N}, \boldsymbol{N}^{\prime}$-[1,3-Benzene-\{diyl-bis-(iminocarbonyl)-4-chloro-6-methyl\}-bis\{1-(3,4-dimethoxybenzyl)-6,7-dimethoxy-1,2,3,4-tetrahydroisoquinoline\}] (13) Synthesized, from 5 and 4-chloro-6-methyl- $m$-phenylenediisocyanate, in a manner similar to that described for 51. The product was obtained as a viscous solid $(84 \%)$. ${ }^{1} \mathrm{H}-\mathrm{NMR}\left(\mathrm{CDCl}_{3}, 300 \mathrm{MHz}\right) \delta: 2.68(4 \mathrm{H}$, m), $2.98(4 \mathrm{H}, \mathrm{m}), 3.24(4 \mathrm{H}, \mathrm{m}), 3.61(3 \mathrm{H}, \mathrm{s}), 3.72(2 \times 3 \mathrm{H}, \mathrm{s}), 3.79(2 \times 3 \mathrm{H}$ s), $3.87(4 \times 3 \mathrm{H}, \mathrm{s}), 5.13(2 \mathrm{H}, \mathrm{m}), 5.85(2 \mathrm{H}, \mathrm{m}), 6.30(2 \mathrm{H}, \mathrm{m}), 6.67(6 \mathrm{H}, \mathrm{m})$, $7.05(2 \mathrm{H}, \mathrm{m}), 7.99(2 \mathrm{H}, \mathrm{s}), 8.05(1 \mathrm{H}, \mathrm{s})$. IR $v(\mathrm{KBr}) \mathrm{cm}^{-1}: 1654$. MS $(\mathrm{m} / \mathrm{z})$ : $895.5(\mathrm{M}+\mathrm{H})^{+}$. Anal. Calcd for $\mathrm{C}_{49} \mathrm{H}_{55} \mathrm{~N}_{4} \mathrm{O}_{10} \mathrm{Cl}: \mathrm{C}, 65.72 ; \mathrm{H}, 6.19 ; \mathrm{N}, 6.25$. Found: C, 65.57; H, 6.24; N, 6.41.

$N, N^{\prime}$-Bis-[2-acetyl-1-(3,4-dimethoxybenzyl)-6,7-dimethoxy-1,2,3,4tetrahydroisoquinoline] (15) To a solution of 1-(3,4-dimethoxybenzyl)- 2-chloroacetyl-6,7-dimethoxy-1,2,3,4-tetrahydroisoquinoline (14) $(0.85 \mathrm{~g}$, $2 \mathrm{mmol})$ and tetrahydropapaverine $(5)(0.68 \mathrm{~g}, 2 \mathrm{mmol})$ in acetone $(10 \mathrm{ml})$ was added activated $\mathrm{K}_{2} \mathrm{CO}_{3}(1 \mathrm{~g}, 7.2 \mathrm{mmol})$ and tetrabutylammonium iodide $(0.18 \mathrm{~g}, 0.5 \mathrm{mmol})$. The mixture was stirred for $12 \mathrm{~h}$ at room temperature. After the completion (TLC) of reaction, acetone was evaporated and diluted the reaction mixture with water $(25 \mathrm{ml})$ and extracted with ethylacetate $(3 \times 25 \mathrm{ml})$. The collective organic portion was washed with brine and dried over $\mathrm{Na}_{2} \mathrm{SO}_{4}$. It was concentrated under reduced pressure and the residue was chromatographed on silica gel using ethylacetate-hexane as eluent to obtain pure 47 as a white solid $(1.08 \mathrm{~g}, 75 \%) \mathrm{mp} 74-75^{\circ} \mathrm{C} .{ }^{1} \mathrm{H}-\mathrm{NMR}$ $\left(\mathrm{CDCl}_{3}, 300 \mathrm{MHz}\right) \delta: 2.45(4 \mathrm{H}, \mathrm{m}), 3.04(4 \mathrm{H}, \mathrm{m}), 3.39(4 \mathrm{H}, \mathrm{m}), 3.50(2 \mathrm{H}$, s), $3.74(2 \times 3 \mathrm{H}, \mathrm{s}), 3.81(2 \times 3 \mathrm{H}, \mathrm{s}), 3.87(4 \times 3 \mathrm{H}, \mathrm{s}), 5.07(2 \mathrm{H}, \mathrm{m}), 6.31(2 \mathrm{H}$, s), $6.61(2 \mathrm{H}, \mathrm{s}), 6.80(6 \mathrm{H}, \mathrm{m})$. IR $(\mathrm{KBr}) v \mathrm{~cm}^{-1}: 1635$. MS $(\mathrm{m} / \mathrm{z}): 727$ $(\mathrm{M}+\mathrm{H})^{+}$. Anal. Calcd for $\mathrm{C}_{42} \mathrm{H}_{50} \mathrm{~N}_{2} \mathrm{O}_{9}: \mathrm{C}, 69.40 ; \mathrm{H}, 6.93 ; \mathrm{N}, 3.85$. Found: $\mathrm{C}$, $69.51 ; \mathrm{H}, 6.71 ; \mathrm{N}, 3.81$.

$N, N^{\prime}$-Bis-[2-acetyl-1-(3,4-dimethoxybenzyl)-6,7-dimethoxy-1,2,3,4tetrahydroisoquinolinyl]piperazine (16) To a solution of 1-(3,4dimethoxybenzyl)-2-chloroacetyl-6,7-dimethoxy-1,2,3,4-tetrahydroisoquinoline (14) $(0.85 \mathrm{~g}, 2 \mathrm{mmol})$ and piperazine $(0.086 \mathrm{~g}, 1 \mathrm{mmol})$ in acetone $(10 \mathrm{ml})$ was added activated $\mathrm{K}_{2} \mathrm{CO}_{3}(1 \mathrm{~g}, 7.2 \mathrm{mmol})$ and tetrabutylammonium iodide $(0.18 \mathrm{~g}, 0.5 \mathrm{mmol})$. The mixture was stirred for $12 \mathrm{~h}$ at room temperature. After the completion (tlc) of reaction, acetone was evaporated and diluted the reaction mixture with water $(25 \mathrm{ml})$ and extracted with ethylacetate $(3 \times 25 \mathrm{ml})$. The collective organic portion was washed with brine and dried over $\mathrm{Na}_{2} \mathrm{SO}_{4}$. It was concentrated under reduced pressure and the residue was chromatographed on silica gel using ethylacetate-hexane as eluent to obtain pure 16 as a pale yellow solid $(0.64 \mathrm{~g}, 76 \%) \mathrm{mp} 80-82^{\circ} \mathrm{C} .{ }^{1} \mathrm{H}-$ NMR $\left(\mathrm{CDCl}_{3}, 300 \mathrm{MHz}\right) \delta: 2.84(8 \mathrm{H}, \mathrm{m}), 2.90(4 \mathrm{H}, \mathrm{m}), 2.93(4 \mathrm{H}, \mathrm{m}), 3.09$ $(4 \mathrm{H}, \mathrm{m}), 3.62(4 \mathrm{H}, \mathrm{s}), 3.69(2 \times 3 \mathrm{H}, \mathrm{s}), 3.73(2 \times 3 \mathrm{H}, \mathrm{s}), 3.79(4 \times 3 \mathrm{H}, \mathrm{s})$, $5.07(2 \mathrm{H}, \mathrm{m}), 6.25(1 \mathrm{H}, \mathrm{s}), 6.27(1 \mathrm{H}, \mathrm{s}), 6.60(2 \mathrm{H}, \mathrm{m}), 6.75(6 \mathrm{H}$, m). IR $(\mathrm{KBr}) v \mathrm{~cm}^{-1}:$ 1638. MS $(\mathrm{m} / \mathrm{z}): 853(\mathrm{M}+\mathrm{H})^{+}$. Anal. Calcd for $\mathrm{C}_{48} \mathrm{H}_{60} \mathrm{~N}_{4} \mathrm{O}_{10}: \mathrm{C}, 67.58 ; \mathrm{H}, 7.08 ; \mathrm{N}, 6.79$. Found: $\mathrm{C}, 67.69 ; \mathrm{H}, 7.17 ; \mathrm{N}, 6.84$.

$N, N^{\prime}$-Bis-[2-acetyl-1-(3,4-dimethoxybenzyl)-6,7-dimethoxy-1,2,3,4tetrahydroisoquinolinyl]-2,6-dimethylpiperazine (17) Synthesized, from a solution of $\mathbf{1 4}$ and 2,6-dimethylpiperazine, in a manner similar to that described for 16. The product was obtained as a pale yellow solid (73\%) $\mathrm{mp}$ 63-64 ${ }^{\circ} \mathrm{C} .{ }^{1} \mathrm{H}-\mathrm{NMR}\left(\mathrm{CDCl}_{3}, 300 \mathrm{MHz}\right) \delta: 1.85(6 \mathrm{H}, \mathrm{s}), 2.76(8 \mathrm{H}, \mathrm{m}), 2.87$ $(4 \mathrm{H}, \mathrm{m}), 2.92(4 \mathrm{H}, \mathrm{m}), 3.11(4 \mathrm{H}, \mathrm{m}), 3.55(2 \mathrm{H}, \mathrm{s}), 3.61(2 \mathrm{H}, \mathrm{s}), 3.71(2 \times 3 \mathrm{H}$, s), $3.78(2 \times 3 \mathrm{H}, \mathrm{s}), 3.89(4 \times 3 \mathrm{H}, \mathrm{s}), 5.13(2 \mathrm{H}, \mathrm{m}), 6.24(1 \mathrm{H}, \mathrm{s}), 6.35(1 \mathrm{H}, \mathrm{s})$, $6.65(2 \mathrm{H}, \mathrm{m}), 6.79(6 \mathrm{H}, \mathrm{m})$. IR $v(\mathrm{KBr}) \mathrm{cm}^{-1}: 1639$. MS $(\mathrm{m} / \mathrm{z}): 882$ $(\mathrm{M}+\mathrm{H})^{+}$. Anal. Calcd for $\mathrm{C}_{50} \mathrm{H}_{64} \mathrm{~N}_{4} \mathrm{O}_{10}: \mathrm{C}, 68.16 ; \mathrm{H}, 7.32 ; \mathrm{N}, 6.35$. Found: C, 68.21; H, 7.21; N, 6.41.

$N, N^{\prime}$-Bis-[2-acetyl-1-(3,4-dimethoxybenzyl)-6,7-dimethoxy-1,2,3,4tetrahydroisoquinolinyl]homopiperazine (18) Synthesized, from a solution of $\mathbf{1 4}$ and homopiperazine, in a manner similar to that described for $\mathbf{1 6}$. The product was obtained as a light yellow solid $(75 \%) \mathrm{mp} 100-102{ }^{\circ} \mathrm{C}$. ${ }^{1} \mathrm{H}-\mathrm{NMR}\left(\mathrm{CDCl}_{3}, 300 \mathrm{MHz}\right) \delta: 2.53(10 \mathrm{H}, \mathrm{m}), 2.81(8 \mathrm{H}, \mathrm{m}), 2.97(4 \mathrm{H}, \mathrm{m})$, $3.31(4 \mathrm{H}, \mathrm{m}), 3.72(2 \times 3 \mathrm{H}, \mathrm{s}), 3.77(2 \times 3 \mathrm{H}, \mathrm{s}), 3.83(4 \times 3 \mathrm{H}, \mathrm{s}), 5.57(2 \mathrm{H}$, $\mathrm{m}), 6.15(1 \mathrm{H}, \mathrm{s}), 6.18(1 \mathrm{H}, \mathrm{s}), 6.69(8 \mathrm{H}, \mathrm{m}) . \mathrm{IR}(\mathrm{KBr}) v \mathrm{~cm}^{-1}: 1635$. MS $(m / z): 867(\mathrm{M}+\mathrm{H})^{+}$. Anal. Calcd for $\mathrm{C}_{49} \mathrm{H}_{62} \mathrm{~N}_{4} \mathrm{O}_{10}: \mathrm{C}, 67.87 ; \mathrm{H}, 6.04 ; \mathrm{N}$, 7.20. Found: C, $67.81 ; \mathrm{H}, 6.11 ; \mathrm{N}, 7.31$

$N, N^{\prime}$-Bis-[1-(3,4-dimethoxybenzyl)-6,7-dimethoxy-1,2,3,4-tetrahydroisoquinoline]urea (21) To a solution of cationic carbamoyl imidazolium salt of $19(0.88 \mathrm{~g}, 2 \mathrm{mmol})$ and tetrahydropapaverine $(0.68 \mathrm{~g}$, $2 \mathrm{mmol})$ in anhydrous dichloromethane was added triethylamine $(0.27 \mathrm{ml}$, $2.0 \mathrm{mmol}$ ). The mixture was stirred at room temperature for $12 \mathrm{~h}$, then washed with $1.0 \mathrm{M} \mathrm{HCl}(10 \mathrm{ml})$, the organic layer dried over anhydrous $\mathrm{Na}_{2} \mathrm{SO}_{4}$, filtered and concentrated under vacuum to yield the required tetra substituted urea as an oil which was column chromatographed (ethylacetate-hexane) to obtain pure $\mathbf{2 1}$ as a white solid $(1.12 \mathrm{~g}, 79 \%) \mathrm{mp} 68$ $69^{\circ} \mathrm{C} .{ }^{1} \mathrm{H}-\mathrm{NMR}\left(\mathrm{CDCl}_{3}, 300 \mathrm{MHz}\right) \delta: 2.43(4 \mathrm{H}, \mathrm{m}), 2.92(4 \mathrm{H}, \mathrm{m}), 3.35(4 \mathrm{H}$, m), $3.72(2 \times 3 \mathrm{H}, \mathrm{s}), 3.79(2 \times 3 \mathrm{H}, \mathrm{s}), 3.88(4 \times 3 \mathrm{H}, \mathrm{s}), 5.05(2 \mathrm{H}, \mathrm{m}), 6.30$ $(2 \mathrm{H}, \mathrm{s}), 6.55(2 \mathrm{H}, \mathrm{s}), 6.67(6 \mathrm{H}, \mathrm{m})$. IR $(\mathrm{KBr}) v \mathrm{~cm}^{-1}: 1633.5$. MS $(\mathrm{m} / \mathrm{z}): 713$ $(\mathrm{M}+\mathrm{H})^{+}$. Anal. Calcd for $\mathrm{C}_{41} \mathrm{H}_{48} \mathrm{~N}_{2} \mathrm{O}_{9}: \mathrm{C}, 69.08 ; \mathrm{H}, 6.78 ; \mathrm{N}, 3.92$. Found: $\mathrm{C}$, $69.18 ; \mathrm{H}, 6.71 ; \mathrm{N}, 3.81$

$N, N^{\prime}$-Bis-[2-carbamoyl-1-(3,4-dimethoxybenzyl)-6,7-dimethoxy1,2,3,4-tetrahydroisoquinolinyl]piperazine (22) To a solution of cationic carbamoyl imidazolium salt of $19(0.88 \mathrm{~g}, 2 \mathrm{mmol})$ and piperazine $(0.086 \mathrm{~g}$, $1 \mathrm{mmol})$ in dichloromethane was added triethylamine $(0.27 \mathrm{ml}, 2.0 \mathrm{mmol})$. The mixture was stirred at room temperature for $12 \mathrm{~h}$, then washed with $1.0 \mathrm{M} \mathrm{HCl}(10 \mathrm{ml})$, the organic layer dried over anhydrous $\mathrm{Na}_{2} \mathrm{SO}_{4}$, filtered and concentrated under vacuum to yield the required tetra substituted urea as an oil which was column chromatographed (ethylacetate-hexane) to obtain pure 22 as a light yellow solid $(0.61 \mathrm{~g}, 75 \%) \mathrm{mp} 73-74{ }^{\circ} \mathrm{C} .{ }^{1} \mathrm{H}-\mathrm{NMR}$ 
$\left(\mathrm{CDCl}_{3}, 300 \mathrm{MHz}\right) \delta: 2.73(8 \mathrm{H}, \mathrm{m}), 2.88(4 \mathrm{H}, \mathrm{m}), 2.92(4 \mathrm{H}, \mathrm{m}), 3.03(4 \mathrm{H}$, m), $3.67(2 \times 3 \mathrm{H}, \mathrm{s}), 3.71(2 \times 3 \mathrm{H}, \mathrm{s}), 3.77(4 \times 3 \mathrm{H}, \mathrm{s}), 5.05(2 \mathrm{H}, \mathrm{m}), 6.23$ $(1 \mathrm{H}, \mathrm{s}), 6.26(1 \mathrm{H}, \mathrm{s}), 6.58(2 \mathrm{H}, \mathrm{m}), 6.72(6 \mathrm{H}, \mathrm{m}) . \mathrm{IR} v(\mathrm{KBr}) \mathrm{cm}^{-1}: 1637$. MS $(m / z): 825(\mathrm{M}+\mathrm{H})^{+}$. Anal. Calcd for $\mathrm{C}_{46} \mathrm{H}_{56} \mathrm{~N}_{4} \mathrm{O}_{10}: \mathrm{C}, 66.97 ; \mathrm{H}, 6.84 ; \mathrm{N}$, 6.79. Found: C, 66.58; H, 6.71; N, 6.81.

$N, N^{\prime}$-Bis-[2-carbamoyl-1-(3,4-dimethoxybenzyl)-6,7-dimethoxy1,2,3,4-tetrahydroisoquinolinyl]-2,6-dimethylpiperazine (23) Synthesized, from cationic carbamoyl imidazolium salt of $\mathbf{1 9}$ and 2,6-dimethylpiperazine, in a manner similar to that described for 22. The product was obtained as a viscous solid $(80 \%)$. ${ }^{1} \mathrm{H}-\mathrm{NMR}\left(\mathrm{CDCl}_{3}, 300 \mathrm{MHz}\right) \delta: 1.80$ $(6 \mathrm{H}, \mathrm{s}), 2.70(8 \mathrm{H}, \mathrm{m}), 2.90(4 \mathrm{H}, \mathrm{m}), 2.93(4 \mathrm{H}, \mathrm{m}), 3.08(4 \mathrm{H}, \mathrm{m}), 3.69$ $(2 \times 3 \mathrm{H}, \mathrm{s}), 3.75(2 \times 3 \mathrm{H}, \mathrm{s}), 3.87(4 \times 3 \mathrm{H}, \mathrm{s}), 5.15(2 \mathrm{H}, \mathrm{m}), 6.27(1 \mathrm{H}, \mathrm{s}), 6.29$ $(1 \mathrm{H}, \mathrm{s}), 6.64(2 \mathrm{H}, \mathrm{m}), 6.74(6 \mathrm{H}, \mathrm{m})$. IR $(\mathrm{KBr}) v \mathrm{~cm}^{-1}: 1635$. MS $(\mathrm{m} / \mathrm{z}): 853$ $(\mathrm{M}+\mathrm{H})^{+}$. Anal. Calcd for $\mathrm{C}_{48} \mathrm{H}_{60} \mathrm{~N}_{4} \mathrm{O}_{10}: \mathrm{C}, 67.58 ; \mathrm{H}, 7.08 ; \mathrm{N}, 6.79$. Found: $\mathrm{C}, 67.51 ; \mathrm{H}, 7.11 ; \mathrm{N}, 6.81$.

$N, N^{\prime}$-Bis-[2-carbamoyl-1-(3,4-dimethoxybenzyl)-6,7-dimethoxy1,2,3,4-tetrahydroisoquinolinyl]homopiperazine (24) Synthesized, from cationic carbamoyl imidazolium salt of $\mathbf{1 9}$ and homopiperazine, in a manner similar to that described for 44 . The product was obtained as a white solid $(76 \%) \mathrm{mp} 82-83^{\circ} \mathrm{C} .{ }^{1} \mathrm{H}-\mathrm{NMR}\left(\mathrm{CDCl}_{3}, 300 \mathrm{MHz}\right) \delta: 2.73(10 \mathrm{H}, \mathrm{m}), 3.07$ $(4 \mathrm{H}, \mathrm{m}), 3.15(4 \mathrm{H}, \mathrm{m}), 3.29(4 \mathrm{H}, \mathrm{m}), 3.64(2 \times 3 \mathrm{H}, \mathrm{s}), 3.82(2 \times 3 \mathrm{H}, \mathrm{s}), 3.89$ $(4 \times 3 \mathrm{H}, \mathrm{s}), 4.95(2 \mathrm{H}, \mathrm{m}), 6.17(1 \mathrm{H}, \mathrm{s}), 6.24(1 \mathrm{H}, \mathrm{s}), 6.56(2 \mathrm{H}, \mathrm{s}), 6.70(6 \mathrm{H}$, m). IR $(\mathrm{KBr}) v \mathrm{~cm}^{-1}:$ 1633. MS $(\mathrm{m} / \mathrm{z}): 839(\mathrm{M}+\mathrm{H})^{+}$. Anal. Calcd for $\mathrm{C}_{47} \mathrm{H}_{58} \mathrm{~N}_{4} \mathrm{O}_{10}: \mathrm{C}, 67.28 ; \mathrm{H}, 6.85 ; \mathrm{N}, 6.67$. Found: $\mathrm{C}, 67.51 ; \mathrm{H}, 6.79 ; \mathrm{N}, 6.81$.

Pharmacological Methods Antispasmodic activity: isolated guinea pig ileum Guinea pigs of both sexes $(300-500 \mathrm{~g})$ were sacrificed by cervical dislocation and exsanguinated. The abdomen was opened and the terminal ileum carefully dissected, repeatedly washed and the connective tissue removed. Intestinal segments of 1.0 to $1.5 \mathrm{~cm}$ length were set up under $1 \mathrm{~g}$ resting tension in a $10 \mathrm{ml}$ organ bath with Tyrode's solution: (mM: $\mathrm{NaCl} 137$, $\mathrm{KCl} 2.7, \mathrm{CaCl}_{2} 1.8, \mathrm{MgCl}_{2} 1.05, \mathrm{NaHCO}_{3} 11.9, \mathrm{NaH}_{2} \mathrm{PO}_{4}$ 0.42, glucose 5.6). The bath temperature was maintained at $37^{\circ} \mathrm{C}$ and aerated with compressed air. Tension changes in the tissues were monitored using force displacement transducer amplifier connected to physiograph (Polyrite, Recorders and Medicare System).

After 30 min of equilibration period, concentration-response curves to the cumulative addition of acetylcholine $(\mathrm{ACh})(0.1 \mathrm{~nm}-0.1 \mathrm{~mm})$ were constructed. After constant responses had been obtained, concentration-response was repeated in the presence of increasing concentrations of the standard antagonist papaverine $(0.1-20 \mu \mathrm{M})$. After a further control experiment (concentration-response curve of $\mathrm{ACh}$ ) the test compounds 6-13, 15-18 and 21-24 were measured. All substances were incubated $3 \mathrm{~min}$ prior to the cumulative addition of ACh; after each experiment all substances were carefully washed out. For each test substance a new ileum preparation was used. Test compounds were dissolved in $46 \%$ EtOH to yield solutions $(0.1-$ $20 \mu \mathrm{M})$. The antispasmodic activity was assessed as a percent reduction over the initial value. The $\mathrm{IC}_{50}$ values (concentration required to inhibit the $100 \%$ $\left[E_{\max }\right]$ Ach response to $50 \%$ ) were obtained from individual experiments with 3 to 5 different concentrations of test compounds. As EtOH in the concentration used also inhibits ACh-induced contractions the antispasmodic activity of EtOH was measured and subtracted from the values obtained with test compounds.

Acknowledgements We are grateful to University Grant Commission for the award of SRF to one of us (JK), New Delhi and Dr. B. R. Ambedkar Centre for Biomedical Research for providing financial assistance and research facilities for carrying out this work.

\section{References}

1) Jiang B., Yang C. G., Xiong W. N., Wang J., Bioorg. Med. Chem., 9, 1149 (2001).

2) Spicer J. A., Gamage S. A., Finlay G. J., Denny W. A., Bioorg. Med Chem., 10, 19 (2002).

3) Cobb P. W., Degen D. R., Clark G. M., Chen S.-F., Kuhn J. G., Gross J L., Kirshenbaum M. R., Sun J.-H., Burris H. A., Von Hoff D. D., J. Natl. Cancer Inst., 86, 1462 (1994).

4) Kirshenbaum M. R., Chen S.-F., Behrens C. H., Papp L. M., Stafford M. M., Sun J. H., Behrens D. L., Fredricks J. R., Polkus S. T., Sipple P., Patten A. D., Dexter D., Seitz S. P., Cancer Res., 54, 2199 (1994).

5) McRipley R. J., Burns-Horwitz P. E., Czerniak P. M., Diamond R. J., Diamond M. A., Miller J. L. D., Page R. J., Dexter D. L., Chen S. F., Sun J. H., Behrens C. H., Seitz S. P., Gross J. L., Cancer Res., 54, 159 (1994).

6) Houghton P. J., Cheshire P. J., Hallman J. C., Gross G. L., McRipley R. J., Sun J. H., Behrens C. H., Dexter D. L., Houghton J. A., Cancer Chemother. Pharmacol., 33, 265 (1994).

7) Thompson J., Pratt C. B., Stewart C. F., Avery L., Zamboni W. C., Pappo A., Inv. New Drugs, 16, 45 (1998).

8) O’Reilly S., Baker S. D., Sartorius S., Rowinsky E. K., Finizio M., Lubiniecki G. M., Grochow L. B., Gray J. E., Pieniaszek H. J., Donehower R. C., Ann. Oncol., 9, 101 (1998).

9) Brana M. F., Castellano J. M., Perron D., Maher C., Conlon D., Bosquet P. F., George J., Qian X. D., Robinson S. P., J. Med. Chem., 40, 449 (1997).

10) Hernandez L., Cholody W. M., Hudson E. A., Resau J. H., Pauly G., Michejda C. J., Cancer Res., 55, 2338 (1995).

11) Cholody W. M., Hernandez L., Hassner L., Scudiero D. A., Djurickovic D. B., Michejda C. J., J. Med. Chem., 38, 3043 (1995).

12) Kusnierczyk H., Cholody W. M., Paradziej-Lukowicz J., Radzikowski C., Konopa J., Arch. Immunol. Ther. Exp., 42, 415 (1994).

13) Leng F., Priebe W., Chaires J. B., Biochemistry, 37, 1743 (1998).

14) Chaire J. B., Leng F., Przewloka T., Fokt I., Ling Y. H., Perez-soler R., Priebe W., J. Med. Chem., 40, 261 (1997).

15) Gamage S. A., Spicer J. A., Atwell G. J., Finlay G. J., Baguley B. C., Denny W. A., J. Med. Chem., 42, 2383 (1999).

16) Spicer J. A., Gamage S. A., Rewcastle G. W., Finlay G. J., Bridewell D. J. A., Baguley B. C., Denny W. A., J. Med. Chem., 43, 1350 (2000).

17) Spicer J. A., Gamage S. A., Finlay G. J., Stewart A. J., Charlton P., Baguley B. C., Denny W. A., J. Med. Chem., 44, 1407 (2001).

18) Deady L. W., Desneves J., Kaye A. J., Finlay G. J., Baguley B. C., Denny W. A., Bioorg. Med. Chem., 8, 977 (2000).

19) Spicer J. A., Gamage S. A., Atwell G. J., Finlay G. J., Baguley B. C., Denny W. A., Anti-Cancer Drug Des., 14, 281 (1999).

20) Nishizawa Y., Nature (London), 308, 693 (1984).

21) Kim H. S., Zhang Y. H., Yun Y. P., Planta Med., 65, 135 (1999).

22) Dong H., Lee C. M., Huang W. L., Peng S. X., Br. J. Pharmacol., 107, 262 (1992).

23) Huddart H., Saad K. H. M., J. Exp. Biol., 86, 99 (1980).

24) Kazan S., Acta Neurol. Scand., 98, 354 (1998).

25) Chandra R., Kaur J., Talwar A., Ghosh N. N., Arkives Org. Chem., VIII, 129 (2001).

26) Kaur J., Ghosh N. N., Talwar A., Chandra R., Chem. Pharm. Bull., 50, 1223 (2002).

27) Batey R. A., Santhakumar V., Ishii C. Y., Taylor S. D., Tetrahedron Lett., 39, 6267 (1998). 